\title{
Liveweight gain per head and per ha throughout the year of lambs grazing conventional pastures and those that switch from grass to clover
}

\author{
A.M. NICOL, R.H. BRYANT, M.J. RIDGWAY and G.R. EDWARDS \\ Faculty of Agriculture and Life Sciences, P.O. Box 84, Lincoln University, Lincoln \\ nicol@lincoln.ac.nz
}

\begin{abstract}
Intensive lamb finishing requires a consistent supply of high quality forage throughout the year to regularly finish lambs. Per head and per ha liveweight gain of weaned lambs was compared in 13 batches of lambs on replicated irrigated farmlets for 2.5 years from conventional mixed tetraploid perennial ryegrasswhite clover pastures (Conv) and pastures that were pure white clover for spring and summer and switched to overdrilled Italian ryegrass for the winter (Switch). Seasonal differences in stocking rate (lambs/ha), liveweight gain per head and per ha were significant $(\mathrm{P}<0.05)$. Average daily liveweight gain/ha was significantly higher $(6.01$ versus $5.66 \mathrm{~kg} / \mathrm{ha} / \mathrm{day}$ for Switch and Conv, respectively, but the total grazing days were slightly lower on the Switch farmlets resulting in similar annualised liveweight gain per ha $(1800 \mathrm{~kg})$ and net carcass weight $(800 \mathrm{~kg} / \mathrm{ha})$ on both pasture treatments. The farmlets apparently utilised $10000 \mathrm{~kg} \mathrm{DM} / \mathrm{ha} / \mathrm{yr}$ of the $16000 \mathrm{~kg}$ DM accumulated.
\end{abstract} Keywords: lamb finishing, annual productivity, farmlets

\section{Introduction}

The increasing demand for heavier lambs on a more regular basis to supply the chilled export market has resulted in an increasing number of intensively managed, lowland lamb finishing properties. Intensive production requires a consistent supply of high quality forage throughout the year to regularly finish lambs. Perennial ryegrass-clover pastures often fail to deliver this due to limited winter growth and a low proportion of clover in the pasture at critical times. The proportion of clover in perennial pastures is typically between $10-20 \%$ (Hoglund et al. 1979) and this is too low to contribute substantially to the animals' nutrient intake. Pure legume pastures promote greater lamb liveweight gain than ryegrass (Fraser \& Rowarth 1996; Speijers et al. 2004) largely attributable to their higher rate of intake, faster rate of degradation and higher total intake. However, total annual livestock production from legumes is limited by their short growing season (Hoglund et al. 1979). Alternative pasture management options that seasonally combine different pasture species may be required to deliver a more regular pasture supply.

One possible opportunity for enhancing lamb production throughout the year may involve a system where annual ryegrass is direct-drilled into white clover in autumn each year. Switching from legume to annual ryegrass in autumn may enhance winter forage production and allow the grass to benefit from the soil nitrogen fixed by the clover during summer.

This paper reports the results of a comparison of continuous lamb finishing on two farmlets: a Switch pasture where annual ryegrass was direct-drilled into a white clover pasture each autumn and allowed to return to clover in spring, and a conventional perennial ryegrass-white clover pasture. The target was to grow batches of lambs on each pasture type from around 27 to $40 \mathrm{~kg}$ liveweight (17.0 kg carcass weight) in 8 weeks (an average liveweight gain of $230 \mathrm{~g} /$ day).

\section{Methods \\ The farmlets}

An area of 3.8 ha was subdivided into 4 blocks ( 3 of 1 ha and 1 of 0.8 ha). Half of each block was randomly allocated to a Switch pasture ('Apex' white clover, 3 $\mathrm{kg} / \mathrm{ha}$ ) or a conventional pasture (Conv, 'Bealey' NEA2 tetraploid ryegrass at $20 \mathrm{~kg} / \mathrm{ha}$ and 'Apex' white clover at $3 \mathrm{~kg} / \mathrm{ha}$ ) totalling eight plots. The pastures were established in the spring of 2005 following spraying (glyphosate, $2 \mathrm{~L} / \mathrm{ha}$ ) and cultivation. Each of the eight plots was fenced with traditional or semi-permanent fences and supplied with stock water; they were divided into four by temporary electric fencing to provide for a rotational grazing system within each plot. Spray irrigation was applied (approximated $50 \mathrm{~mm}$ per application) when required. Switch pastures were overdrilled with annual ryegrass ('Andy' tetraploid ryegrass, $20 \mathrm{~kg} / \mathrm{ha}$ ) on 15 March 2006 and again on 12 March in 2007. Continued persistence of the annual ryegrass in late spring 2006 prompted chemical removal in November 2007 with glyphosate $(1 \mathrm{~L} / \mathrm{ha}$ at 360 a.i./L).

\section{Lambs}

Lambs were bought-in as required and varied between batches in breed, sex and initial average liveweight and within batches by sex and initial liveweight (average liveweight $27.9 \mathrm{~kg}$, range per batch was 23.3 to 33.5 
$\mathrm{kg}$ ). Lambs were allocated by liveweight and sex to all eight plots. Lambs were usually weighed off pasture after about 4 weeks and always at the end of each batch (around 8 weeks). All lambs received a quarantine anthelmintic treatment (product dependent on farm policy) before being placed on the plots. Lambs were either shorn before their use or sold as woolly lambs at the end of the batch period with the exception of one batch (Merino lambs, batch 5) that were shorn during the period. At the end of each batch, lambs which had reached the target slaughter weight were slaughtered and mean carcass weight recorded. The mean carcass weight was divided by the final liveweight of these lambs to give a dressing out $\%$ for each batch of lambs. Total carcass weight gain of each group was taken as the total liveweight gain multiplied by the mean dressing out $\%$ of the lambs that were slaughtered.

\section{Grazing management}

Pasture growth rate and botanical composition were determined at the beginning of each grazing rotation (with exception of a missed sampling in February 2007) from $0.2 \mathrm{~m}^{2}$ quadrat cut to $2 \mathrm{~cm}$ beneath exclusion cages. Cages were shifted to a new area following sampling, previously mown to a residual height of 2 $\mathrm{cm}$. Sub-samples of known weight from the pre-grazing cuts were retained for botanical analysis. Samples were dried in a forced-air oven at $70^{\circ} \mathrm{C}$ for $48 \mathrm{~h}$. Lambs were rotationally grazed with the stocking rate, duration of grazing and interval between grazing adjusted between and within batches for pasture growth rate and cover, assessed visually. No pasture was conserved but topping was employed when necessary to maintain pasture quality.

\section{Statistical analysis}

Data for each batch were grouped into season and farmlet type and a split-plot ANOVA was performed in Genstat (v 12) to determine the effect of farmlet type, season and their interaction.

\section{Results}

Table 1 The season and year distribution of all batches of lambs carried on the Switch and Conventional farmlets and the interval between batches.

\begin{tabular}{lccccccccccccccc}
\hline Batch & 1 & 2 & 3 & 4 & 5 & 6 & 7 & 8 & 9 & 10 & 11 & 12 & 13 \\
Season & Sum & Aut & Aut & Win & Spr & Sum & Aut & Win & Win & Spr & Spr & Sum & Sum \\
Year & 2005 & 2006 & 2006 & 2006 & 2006 & 2007 & 2007 & 2007 & 2007 & 2007 & 2007 & 2008 & 2008 \\
Duration (days) & 46 & 48 & 50 & 68 & 76 & 61 & 99 & 50 & 62 & 39 & 35 & 38 & 62 \\
Interval (days) & & 5 & 29 & 8 & 0 & 0 & 21 & 9 & 1 & 7 & 0 & 19 & 7 \\
\hline
\end{tabular}

The pasture type comparison farmlets ran for 800 days, representing 13 batches of lambs with an average period of 61 days made up of 53 days grazing (range 28 to 99 days) and an average interval of 8 days between batches (range 0 to 29 days), the equivalent of 5.3 batches/annum. The season and year distribution of the batches is shown in Table 1. Results are presented per lamb and per ha 'by season' and on an annual basis.

\section{Pasture production and composition}

Through the experimental period pasture growth rate did not differ significantly between the Switch and Conv pastures (Fig. 1) except $(\mathrm{P}<0.05)$ in winter (June) 2006 due to slow establishment of the annual ryegrass. Total annualised DM production was estimated to be 16250 and $15960 \mathrm{~kg} \mathrm{DM} / \mathrm{ha}$ for Switch and Conv pastures, respectively.

Clover content (\% of DM) was significantly greater in Switch than Conv throughout the majority of the experimental period (Fig. 2). The difference between treatments was less in spring 2006 as annual ryegrass dominated in the Switch farmlets (Fig. 2). Spraying of annual ryegrass in the Switch treatment in November 2007 resulted in renewed clover dominance (data not presented) in this treatment for batches 12 and 13 (Table 1). The proportion of ryegrass in the pastures was essentially the inverse of values in Fig. 2 as there were few weeds or other species present $(<5 \%$ of DM).

\section{Per lamb}

The mean liveweight of lambs coming onto, and leaving the farmlets was 27.9 (batch range, 23.0 to $33.5 \mathrm{~kg}$ ) and $38.2 \mathrm{~kg}$ (batch range, 36.8 to $42.0 \mathrm{~kg}$ ), respectively. There was no significant difference in the average liveweight of lambs leaving the Switch or Conv farmlets (Table 2) as a consequence of no overall difference in average liveweight gain (216 and $206 \mathrm{~g} /$ day for Switch and Conv, respectively) or in the average length of each period (Table 2).

On both farmlets, liveweight gain was significantly higher in spring than in summer or winter, which in turn was significantly higher than autumn due entirely 
Table 2 The average per head productivity of lambs on the Switch and Conv farmlets.

\begin{tabular}{|c|c|c|c|c|c|c|}
\hline \multirow[t]{2}{*}{ Trait } & \multirow{2}{*}{$\begin{array}{l}\text { Pasture } \\
\text { type }\end{array}$} & \multicolumn{4}{|c|}{ Season } & \multirow[t]{2}{*}{ Average } \\
\hline & & Spring & Summer & Autumn & Winter & \\
\hline \multirow[t]{3}{*}{ Liveweight gain (g/day) } & Both & $251 a$ & $202 b$ & $176 c$ & $218 b$ & 211 \\
\hline & Switch & 244 & $222 y$ & 171 & 225 & 216 \\
\hline & Conv & 257 & $182 z$ & 180 & 211 & 206 \\
\hline \multirow[t]{2}{*}{ Final liveweight (kg) } & Switch & 40.0 & 38.5 & 35.8 & 38.7 & 40.1 \\
\hline & Conv & 40.2 & 37.1 & 36.7 & 39.3 & 39.1 \\
\hline \multirow[t]{2}{*}{ \% Slaughtered } & Switch & 73.7 & 86.7 & 72.2 & 71.9 & 77.2 \\
\hline & Conv & 87.6 & 81.5 & 79.0 & 77.8 & 81.8 \\
\hline \multirow[t]{3}{*}{ Carcass weight (kg) } & Both & $17.5 \mathrm{ab}$ & $16.6 \mathbf{a b}$ & $16.4 b$ & $18.6 \mathbf{a}$ & 17.2 \\
\hline & Switch & 17.9 & 16.8 & 16.7 & 19.0 & 17.4 \\
\hline & Conv & 17.0 & 16.4 & 16.0 & 18.2 & 16.8 \\
\hline \multirow[t]{2}{*}{ Dresssing out \% } & Switch & 43.5 & 42.6 & 43.2 & 45.3 & 43.3 \\
\hline & Conv & 42.1 & 43.1 & 41.9 & 44.5 & 42.7 \\
\hline
\end{tabular}

Values for season effects followed by letters a to $\mathbf{d}$ are significantly different $(P<0.05)$.

Values for pasture effects followed by letters $\mathbf{y}$ and $\mathbf{z}$ are significantly different $(P<0.05)$

Figure 1 Seasonal growth rate of Switch and Conventional (Conv) pastures. Error bars are SEM.

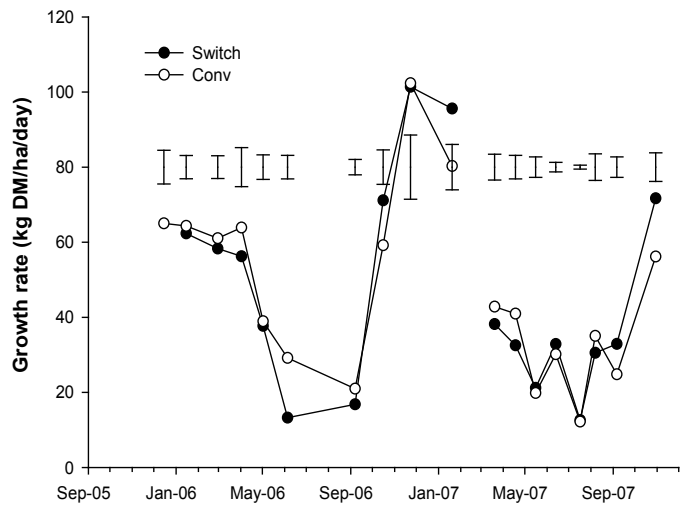

to one autumn batch (2007) where lambs grew slower due to overstocking. Summer was the only season in which lamb liveweight gain was significantly higher on the Switch farmlet. A similar proportion of lambs was slaughtered from both farmlets, but the slightly lighter average final liveweight of Switch lambs combined with a slightly higher dressing out \% (43.3 and 42.7\% for Switch and Conv lambs, respectively), resulted in an average carcass weight advantage of $0.6 \mathrm{~kg}$ to lambs from the Switch farmlet (17.4 and $16.8 \mathrm{~kg}$ for Switch and Conv, respectively).

\section{Per hectare}

The average stocking rate, duration of batches and lamb liveweight gain/ha/day over all batches of lambs was similar for both farmlets (Table 3 ). The average stocking
Figure 2 Clover content (\% of total DM) in Switch (closed symbols) and Conventional (open symbols) pastures. Error bars are SEM.

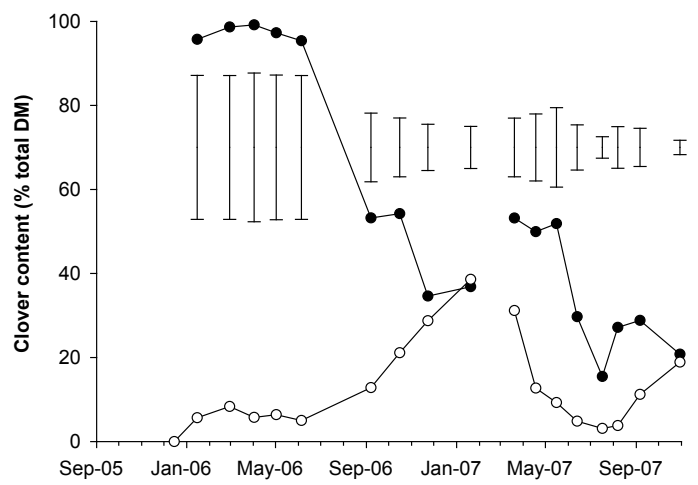

rate was 29.2 lambs/ha although this varied significantly between seasons in line with pasture growth (Fig. 1). Although there was no difference in the overall average stocking rate of the two farmlets, the Switch carried more lambs in spring, less in summer and fewer in winter than the Conv farmlets. Grazing days per batch was significantly longer by around 10 days in autumn and winter but the only significant difference between the farmlets was in summer when lambs where on Conv farmlets for nearly a week longer, reflecting their lower liveweight gain during this period.

The significant seasonal effect on lamb liveweight gain per ha/day mirrored the seasonal effect on stocking rate. Liveweight gain /ha/day was significantly higher on the Switch farmlet in spring and summer but lower in autumn. Overall lamb liveweight gain/ha was 
Table 3 The average stocking rate, grazing days per batch and liveweight gain/ha of lambs on the two farmlets.

\begin{tabular}{|c|c|c|c|c|c|c|}
\hline \multirow[t]{2}{*}{ Trait } & \multicolumn{2}{|l|}{ Pasture } & \multicolumn{3}{|c|}{ Season } & \multirow[t]{2}{*}{ Average } \\
\hline & type & Spring & Summer & Autumn & Winter & \\
\hline \multirow[t]{3}{*}{ Stocking rate (lambs/ha) } & Both & $32.9 b$ & $36.9 a$ & $30.8 c$ & $13.5 d$ & 29.2 \\
\hline & Switch & $38.0 \mathbf{y}$ & $35.4 \mathbf{z}$ & 30.1 & $10.8 \mathbf{z}$ & 29.1 \\
\hline & Conv & $27.8 \mathbf{z}$ & $38.6 y$ & 31.6 & $16.3 y$ & 29.3 \\
\hline \multirow[t]{3}{*}{ Grazing days per batch } & Both & $50.0 c$ & $51.6 c$ & $65.6 \mathbf{a}$ & $59.8 b$ & 56.4 \\
\hline & Switch & 49.5 & $48.6 z$ & 63.9 & 56.1 & 54.9 \\
\hline & Conv & 50.5 & $54.5 y$ & 67.3 & 59.8 & 57.9 \\
\hline \multirow[t]{3}{*}{ Liveweight gain (kg/ha/day) } & Both & $8.05 a$ & $7.16 b$ & $4.71 \mathrm{c}$ & $2.97 d$ & 5.83 \\
\hline & Switch & $9.01 \mathbf{y}$ & $7.59 y$ & $4.25 z$ & 2.65 & $6.01 y$ \\
\hline & Conv & $7.09 z$ & $6.74 z$ & $5.16 y$ & 3.29 & $5.66 z$ \\
\hline
\end{tabular}

Values for season effects followed by letters a to $\mathbf{d}$ are significantly different $(P<0.05)$

Values for pasture effects followed by letters $\mathbf{y}$ and $\mathbf{z}$ are significantly different $(P<0.05)$

Table 4 The annualised productivity of the two farmlets.

\begin{tabular}{lcc}
\hline Trait & \multicolumn{2}{c}{ Pasture type } \\
& Switch & Conventional \\
\hline Liveweight gain $(\mathrm{kg} / \mathrm{ha})$ & 1830 & 1845 \\
Carcass weight gain $(\mathrm{kg} / \mathrm{ha})$ & 800 & 790 \\
Grazing days per ha & 8465 & 8975 \\
DM apparently utilised (kg/ha) & 10275 & 10015 \\
\hline
\end{tabular}

significantly higher $(6 \%)$ on the Switch farmlets. The lower average stocking rate and liveweight gain/ha/day for the Switch farmlet in winter reflects the fact that no lambs were carried on this farmlet for the first of the winter batches.

\section{Per annum}

The annualised per ha productivity of the two farmlets (Table 4) shows on average they produced $1840 \mathrm{~kg}$ and nearly $800 \mathrm{~kg}$ of lamb liveweight and carcass weight/ha/yr, respectively. The apparent DM utilised per ha, of $10000 \mathrm{~kg} \mathrm{DM} / \mathrm{ha} / \mathrm{yr}$ was calculated from the metabolisable energy requirements of the lambs (Nicol \& Brookes 2007) based on the average initial lamb liveweight, liveweight gain and days per batch.

The higher grazing days per ha on Conv farmlets reflects the greater average number of batches per year on the Conv farmlets. However, the slightly higher stocking rate and liveweight gain of Switch lambs counteracts the fewer number of batches so that the total liveweight gain, carcass weight gain and apparent DM utilised per ha was similar for both farmlets.

\section{Discussion}

The objective of achieving a continuous annual output of finished lambs by adding $12 \mathrm{~kg}$ liveweight over 8 weeks at $230 \mathrm{~g}$ /day was almost achieved in both farmlets (Tables $2 \& 3$ ). After allowing for a pasture establishment of 60 days and due to the short turnover time between batches there were on average 5.3 batches of lambs per year. Although the targets were almost met, 300 of the over 1400 lambs (20\%) failed to meet target weight for slaughter. These lambs did not return to the farmlets as members of the next batch. Given that these 'store' lambs at the end of a batch were heavier on average $(33.1 \mathrm{~kg})$ than the average initial weight $(27.9$ $\mathrm{kg}$ ), had they been retained for the next batch it is likely that overall, a higher proportion of lambs would have reached target slaughter weight.

There are few published reports of the seasonal or annual productivity of intensive lamb finishing units to make comparisons with. Intensive bull beef production systems (Clark 1992) produced up to $920 \mathrm{~kg}$ net carcass weight/annum, slightly higher than the $800 \mathrm{~kg}$ net lamb carcass weight produced from these farmlets. Vartha \& Fraser (1978) produced $488 \mathrm{~kg}$ lamb meat $/ \mathrm{ha} / \mathrm{yr}$ from lucerne-'Tama' ryegrass plots but these included breeding ewes. The current results may set a benchmark for intensive lamb finishing.

The overall mean liveweight gain of $215 \mathrm{~g} /$ day is not high compared with some other reported shortterm, post-weaning lamb liveweight gains (Fraser et al. 2004; Fraser \& Rowarth 1996; Speijers et al. 2004) but is at the upper end of the range published for a farm survey (Everest \& Scales 1983). Inconsistency in the average liveweight gain reduced the overall average. For example, $36 \%$ of all plot average liveweight gains 
were $>250 \mathrm{~g} /$ day but $33 \%$ were $<200 \mathrm{~g} /$ day. Inability to consistently maintain a high liveweight gain was due to setting too high a stocking rate for some plot/ seasons, leading to overgrazing and low feed intake; use of lambs with a lower potential for growth in some batches i.e. Merino lambs were used in batch 5 to ensure juvenile teeth were still present at the end of the period to maintain 'lamb' status for the carcasses; and batch 7 when monitoring of the farmlets was compromised.

We estimate, based on the annual pasture production and apparent DM consumed by lambs, that around $63 \%$ of the available DM was utilised by the lambs. This is similar to that achieved with bulls at a low stocking rate (Clark 1992) but much lower than that achieved by bulls and dairy cows at a high stocking rate of closer to 90\% (Clark 1992). Macdonald et al. (2001) estimated pasture utilisation from 63 to $81 \%$ with increasing stocking rate on dairy cow farmlets. We acknowledge that our estimate of pasture production from cage cuts may be greater than that achieved on the grazed area (Orr et al. 1988; McNaughton et al. 1996) and know from the amount of pasture topping that was done, particularly on the Conv farmlet, that utilisation was not as high as possible.

\section{Switch versus conventional system}

The objective of the Switch system was to utilise annual ryegrass to increase the overall stocking rate and winter and early spring productivity of a pure white clover pasture. This was achieved as evidenced by the similar total productivity and seasonal pattern of output of the two farmlets. However, except in summer, the advantage of higher lamb liveweight gain from the legume-based pasture was not obvious. This probably reflects that in winter and spring, ryegrass was the dominant component of the diet of lambs on the Switch farmlet (Fig. 2).

Both systems had their advantages and disadvantages. Although the overdrilling of annual ryegrass into the Switch pastures increased their total annual DM production, the date of establishment was critical to their winter contribution and its removal from the pasture in spring was critical in regaining clover dominance. Vartha \& Fraser (1978) also commented on this aspect in their switch to and from lucerne and 'Tama' ryegrass. Mechanical topping of pastures to removed seedheads was required during late spring and summer to maintain pasture quality but this was much less of an issue with the Switch pastures.

\section{Conclusions}

Intensively managed lamb finishing farmlets produced lambs of a suitable export carcass weight $(17.0 \mathrm{~kg})$ throughout the year resulting in a high annual output of lamb carcass weight per ha. There was little difference in the productivity of conventional ryegrass-white clover-based farmlet and one that annually switched from clover to annual ryegrass.

\section{ACKNOWLEDGEMENTS}

This work was funded by an internal Lincoln University Research Grant INT4052.

\section{REFERENCES}

Clark, D.A. 1992. The effect of stocking rate on bull beef production. Massey Dairyfarming Annual. pp. 15-20.

Everest P.G.; Scales, G.H. 1983. Pre- and post-weaning growth rates of ewes and lambs in the South Island. pp. 41-46. In: Lamb growth Ed. Familton, A.S. Technical Handbook Animal Industries Workshop, Lincoln University.

Fraser, M.D.; Speijers, M.H.M.; Theobald, V.J.; Fychan, R.; Jones, R. 2004. Production performance and meat quality of grazing lambs finished on red clover, lucerne or perennial ryegrass swards. Grass and Forage Science 59: 345-356.

Fraser, T.J.; Rowarth, J.S. 1996. Legumes, herbs or grass for lamb performance? Proceedings of the New Zealand Grassland Association 58: 49-52.

Hogland, J.H.; Crush, J.R.; Brock, J.L.; Ball, R.; Carran, R.A. 1979. Nitrogen fixation in pasture 12. General discussion. New Zealand Journal of Experimental Agriculture 7: 45-51.

Macdonald, K.A.; Penno, J.W.; Nicolas, P.K.; Life, J.A.; Coulter, M.; Lancaster, J.A.S. 2001. Farm systems impact of stocking rate on dairy farm efficiency. Proceedings of the New Zealand Grassland Association 63: 223-227.

McNaughton, S.J.; Milchunas, D.G.; Frank D. A. 1996. How can net primary productivity be measured in grazing ecosystems? Ecology 77: 974-977.

Nicol, A.M.; Brookes, I.M. 2007. The metabolisable energy requirements of grazing livestock. pp. 151172. In: Pastures and Supplements for grazing animals. Ed. Rattray, P.V.; Brookes, I.M.; Nicol, A.M. Occasional Publication No 14, New Zealand Society of Animal Production.

Orr, J.; Parsons, A.J.; Treacher, T.T.; Penning, P.D. 1988. Seasonal patterns of grass production under cutting or continuous stocking managements. Grass and Forage Science 43: 199-207.

Speijers, M.H.M.; Fraser, M.D.; Theobald, V.J.; Haresign, W. 2004. The effects of grazing forage legumes on the performance of finishing lambs. Journal of Agricultural Science 142: 483-493.

Vartha, E.W.; Fraser, T.J. 1978. Lucerne-Tama ryegrass systems for fat lamb production. New Zealand Journal of Experimental Agriculture 6: 195-200. 